\title{
Archival Buildings in Terms of Responding to the Emergencies
}

\author{
JOZEF HANUS, ING. PH.D. \\ Faculty of Chemical and Food Technology, Slovak University of Technology, Radlinského 9, 81237 Bratislava, \\ Slovak Republic \\ e-mail: jozef.hanus@stuba.sk
}

EMILIA HANUSOVÁ, ING.

University Library Bratislava, Michalská 1, 81417 Bratislava, Slovak Republic

e-mail: emilia.hanusova@ulib.sk

\section{Archival Buildings in Terms of Responding to the Emergencies}

\begin{abstract}
Preservation of archival documents, library materials and other objects and materials of cultural heritage is one of the principal tasks of archives, libraries, museums, galleries and other cultural memory institutions all over the world. The key role in this mission is played by appropriate building or space facilities which are the basic condition and requirement for proper functioning of any of these memory cultural institutions. They must provide not only facilities for long-term storage of archival documents, library materials and other objects of cultural heritage, their preservation, processing, treatment in order to enable and ensure proper and safe access to them but also to respond possible emergencies resulting from various potential emergencies and even threats. Some of them can be predicted, however, the others - especially caused by human factor in the broadest sense - are very difficult to be foreseen. This is the reason why close co-operation is unavoidable between archivists, conservators, architects, engineers and all experienced experts who can help already in planning either new building or reconstruction of adapted premises for archives purposes. It seems that at the present also the participation of experts from the field of safety and security would be very desirable.
\end{abstract}

Key words: archives, building, storage, access to archives, archival service, preservation, safety, security, emergency, standards

\section{L'edilizia archivistica in termini di risposta alle emergenze}

\section{SINTESI}

La conservazione di documenti d'archivio, materiale librario e altri oggetti e materiali del patrimonio culturale è uno dei compiti principali di archivi, biblioteche, musei, gallerie e altre istituzioni di memoria culturale in tutto il mondo. Il ruolo chiave in questa missione è interpretato dalle adeguate strutture edifici o spazi che sono condizione di base ed esigenza per il corretto funzionamento di qualsiasi di queste istituzioni culturali di memoria. Essi devono fornire non solo l'archiviazione a lungo termine dei documenti d'archivio, materiale librario e altri oggetti del patrimonio culturale, la loro conservazione, elaborazione, trattamento al fine di consentire e garantire un accesso adeguato e sicuro per loro, ma anche rispondere ad eventuali emergenze e minacce dovute a vari potenziali. Alcuni di essi possono essere previsti, altri, tuttavia - soprattutto quelli causati dal fattore umano nel senso più ampio - sono molto difficili da prevedere. Questo è il motivo per cui è inevitabile una stretta collaborazione tra archivisti, restauratori, architetti, ingegneri ed esperti tutti che possono aiutare già nella pianificazione o nuova costruzione o ricostruzione di locali adattati per scopi di archivio. Al presente sembra che anche la partecipazione di esperti del settore della sicurezza e della sorveglianza sarebbe molto auspicabile.

Parole chiave: archivi, edifici, stoccaggio, accesso agli archivi, servizio archivistico, conservazione, protezione, sicurezza, emergenza, norme

Arhivske zgradbe in njihovo načrtovanje v smislu odzivanja na nevarnost

\section{IZVLE ČEK}

Hramba arhivskega gradiva in knjižničnega gradiva in drugih predmetov kulturne dediščine, je ena izmed glavnih nalog arhivov, knjižnic, muzejev, galerij in drugih kulturnih ustanov po svetu. Ključno vlogo pri tem imajo ustrezni objekti in prostori, ki so osnovni pogoj in hkrati zahteva za pravilno delovanje katere koli od teh kul- 
turnih ustanov. Ti morajo biti primerni za dolgoročno hrambo arhivskega in knjižničnega gradiva in drugih objektov kulturne dediščine, za njihovo ohranjanje, urejanje in obdelavo, ki omogočajo in zagotavljajo ustrezen in varen dostop do gradiva, hkrati pa morajo biti načrtovani tako, da se lahko odzivajo na morebitne izredne razmere, ki izhajajo iz različnih možnih izrednih dogodkov ali celo nevarnosti. Nekatere je mogoče napovedati, medtem ko je druge - predvsem tiste, ki jih povzroča človeški faktor v najširšem smislu - zelo težko predvideti. To je razlog, zakaj je tesno sodelovanje med arhivisti, konservatorji, arhitekti, inženirji in vsemi drugimi strokovnjaki, ki lahko pomagajo pri načrtovanju bodisi novogradnje ali rekonstrukcije že obstoječih prostorov za namene arhiva neizogibno. Zdi se, da bi v sedanjih razmerah bilo zelo zaželeno tudi sodelovanje strokovnjakov $s$ področja varnosti in zaščite.

Ključne besede: arhivi, arhivske zgradbe, hramba, dostop, arhivske službe, konzerviranja, varnost, zaščita, nevarnost, standardi

\section{Archívne budovy z hladiska reakcie na krízové situácie}

\section{ABSTRAKT}

Ochrana archívnych dokumentov, knižničných fondov, ako aj ostatných materiálov a objektov kultúrneho dedičstva je jednou z hlavných úloh archívov, knižníc, múzeí, galérií a ostatných kultúrnych pamätových inštitúcií na celom svete. Klúčovú úlohu v tomto procese zohráva budova, resp. vhodné priestorové možnosti, ktoré sú základnou podmienkou a požiadavkou na správne fungovanie akejkolvek pamätovej kultúrnej inštitúcie. Musia poskytovat nielen možnosti pre dlhodobé uloženie archívnych dokumentov, knižničných materiálov či ostaných objektov kultúrneho dedičstva, ich ochrany, spracovania a sprístupnenia tak, aby sa zabezpečilo ich vhodné a bezpečné sprístupnenie; priestory musia zároveň zabezpečovat aj ochranu pred možnými krízovými situáciami či dokonca hrozbami. Niektoré z týchto situácií sú predvídatelné, iné - najmä tie, ktoré sú spôsobené ludským faktorom v najširšom zmysle - sú len tažko predvídatelné. To je dôvod na čo najužšiu a nevyhnutnú spoluprácu medzi archivármi, konzervátormi a reštaurátormi, architektmi, inžiniermi a ostatnými expertmi, ktorí môžu pomôct už pri plánovaní či rekonštrukcii budov pre archívne účely. Zdá sa, že súčasná doba bude vyžadovat aj spoluprácu so špecialistami z oblasti bezpečnosti.

\section{Three announcements instead of Introduction}

\section{March 2015}

Gunmen wearing military uniforms stormed Tunisia's National museum on Wednesday, killing 17 foreign tourists and two Tunisians in one of the worst militant attacks in a country that had largely escaped the region's "Arab Spring” turmoil. Five Japanese as well as visitors from Italy, Poland and Spain were among the dead in the noon assault on Bardo museum inside the heavily guarded parliament compound in central Tunis, Prime Minister Habib Essid said.

The museum is known for its collection of ancient Tunisian artifacts and mosaics and other treasures from classical Rome and Greece. (Amara and Argoubi, 2015).

\section{July 1976}

On July 21, 1976, the American Legion opened its annual three-day convention at the BellevueStratford Hotel in Philadelphia, Pennsylvania. More than 2,000 Legionnaires, mostly men, attended the convention. The date and city were chosen to coincide with America's celebration of the 200th anniversary of the signing of the Declaration of Independence at Philadelphia in 1776. On July 27, three days after the convention ended, Legionnaire Ray Brennan, a 61-year-old retired Air Force captain and an American Legion bookkeeper, died at his home of an apparent heart attack. Brennan had returned home from the convention on the evening of July 24 complaining of feeling tired. On July 30, another Legionnaire, Frank Aveni, aged 60, also died of an apparent heart attack, as did three other Legionnaires. All of them had been convention attendees. Twenty-four hours later, on August 1 , six more Legionnaires died. Officials at the American Legion also began getting notices of the sudden deaths of several members, all at the same time. Within a week, more than 130 people, mostly men, had been hospitalized, and 25 had died (Time 1976, Altman 2006).

The U.S. Centers for Disease Control and Prevention mounted an unprecedented investigation 
and, by September, the focus had shifted from outside causes, such as a disease carrier, to the hotel environment itself. In January 1977, the Legionella bacterium was finally identified and isolated named according to the sad occasion at the Legionaries convention. It was found to be breeding in the cooling tower of the hotel's air conditioning system (Globe\& Mail 1978) which then spread it through the building (Kotulak 1986, Barrymore 1994).

\section{November 2014}

As of November 12, 2014, 302 people have been hospitalized following an outbreak of Legionella in Portugal and 7 related deaths have been reported. All cases, so far, have emerged in three civil parishes from the municipality of Vila Franca de Xira in the northern outskirts of Lisbon, Portugal and are being treated in hospitals of the Greater Lisbon area. The source is suspected to be located in the cooling towers of the fertilizer plant Fertibéria (Arreigoso 2014).

At the first glance it seems that these events have no connection with the archives and libraries at all and it could be stated there is no need of any mention them at this occasion with relation to the present topic "Archival Buildings in Terms of Responding to the Emergencies".

\section{Role of proper building / space facilities}

Preservation of archival documents, library materials and other objects and materials of cultural heritage is one of the principal tasks of archives, libraries, museums, galleries and other cultural memory institutions all over the world. The key role in this mission is played by appropriate building or space facilities which are the basic condition and requirement for proper functioning of any of these memory cultural institutions. They must provide not only facilities for long-term storage of archival documents, library materials and other objects of cultural heritage, their preservation, processing, treatment in order to enable and ensure proper and safe access to them but also to respond possible emergencies resulting from various potential emergencies and even threats.

Problems of new buildings or reconstruction of adapted premises for archives purposes are among the important activities of the International Council of Archives and also of the International Institute for Archival Science Trieste-Maribor. Original activities of the International Institute for Archival Science (IIAS) Maribor were also oriented in archive buildings by publishing of Modern Archives, later on by Atlanti (Klasinc 2009). Especially many of the first numbers of publication Atlanti are completely devoted to archive buildings and technical equipments from different points of view (Klasinc 2010). Some of them we summarized in our previous publications (Hanus and Hanusová 2011, 2012).

A lot of interesting information as well as useful relevant codes, standards and references are provided in US Whole Building Design Guide WBDG an Archives and Record Storage Building (Acker and O'Connell 2010), especially from the point of emergency view in its part Secure / Safe (WBDG 2014a). Natural and man-made threats of the last decade have focused attention on protection of occupants and assets. Through comprehensive threat assessment, vulnerability assessment, and risk analysis, security requirements for individual buildings are identified, and appropriate reasonable design responses are identified for integration into the building design. Given the mission of this building type, protection of occupants, assets, and building contents is of paramount importance. Protection of valued archival materials from fire and smoke, water, and inadequate environmental conditions, will require robust building and systems design, and reliable, durable, and integrated system sensors, monitors, alarms, and protection devices. In addition man-made threat security shall require controlled access and surveillance systems.

The 2001 terrorist attacks at New York City's World Trade Center and the Pentagon, the 1995 bombing of Oklahoma City's Alfred P. Murrah Federal Office Building, and the 1996 bombing at Atlanta's Centennial Park, and more recently the bombing at the Boston Marathon, shook the nation, and made Americans aware of the need for better ways to protect occupants, assets, and buildings from human aggressors (e.g. disgruntled employees, criminals, vandals, lone active shooter, and terrorists) (WBDG 2014b). In this part information on Security Standards, Design Basis Threat Tactics, Related Issues, Relevant Codes and Standards, Major Resources and Security Risk Management Series Publications (FEMA 2015) are provided. 
What does actually emergency mean? According to one definition (Webster's 1996) it is "an unforeseen combination of circumstances or the resulting state that calls for immediate action" or "a pressing need". According to the other one it is "a situation that poses an immediate risk to health, life, property, or environment (UK Government Advice 2007). Most emergencies require urgent intervention to prevent a worsening of the situation, although in some situations, mitigation may not be possible and agencies may only be able to offer palliative care for the aftermath. Emergency in (UK Guidance 2006) is defined as: an event or situation which threatens serious damage to human welfare in a place in the UK, the environment of a place in the UK, or war or terrorism which threatens serious damage to the security of the UK.

On the basis of all these information and development of the human society at present times it is obvious that the protection against buildings threats emergencies has been shifted from the sphere of possible technical failings and natural disasters to the protection against emergencies caused by intentional human behaviour (above mentioned announcement 1).

On the other hand, the information about possible negative and even mortal impact of microbiological contamination on human beings caused by such obvious and frequently used systems such as air-conditioning is the challenge that the thorough checking of all risk factors and the elimination of these potential threats from archives, libraries, museums and galleries is of the same importance (above mentioned announcements 2, 3).

As microbiological contamination is also a dangerous degradation factor threatening natural organic materials, significant attention is devoted to the development and application of new disinfection and sterilization methods. On the basis of an interdisciplinary cooperation among the Faculty of Chemical and Food Technology of the Slovak University of Technology in Bratislava, the Slovak National Museum and the Sanosil Slovakia SK, Ltd. (Sanosil SK 2012) possibilities for application of ecologically friendly disinfectants Sanosil ${ }^{\odot}$ (Sanosil 2013) for preventive and acute preservation of human health and heritage objects have been examined (Hanus et al. 2014). The project will be completed at the end of this year and the results will be provided to the public.

\section{Reference list}

Acker, E., O‘Connell, P. (2010). Archives and Record Storage Building - Whole Building Design Guide. Available at: http://www.wbdg.org/design/archives_records.php (accessed on 12.06.2015).

Altman, L., K. (2006). In Philadelphia 30 Years Ago, an Eruption of Illness and Fear. New York Times, August 1, 2006. Available at: http://www.nytimes.com/2006/08/01/health/01docs.html?_r=2\&oref=slogin\&pagewan ted=print\& (accessed on 11.06.2015).

Amara, T., Argoubi, M. (2015). Gunmen storm Tunisian museum, kill 17 foreign tourists. Reuters. Available at: http://www.reuters.com/article/2015/03/18/us-tunisia-security-idUSKBN0ME18E20150318 (accessed on 10.06.2015).

Arreigoso, V., L. (2014). Surto de legionella é o terceiro maior de sempre no mundo: 302 infetados e sete mortos. Expresso, November 12, 2014. Available at: http://expresso.sapo.pt/sociedade/surto-de-legionella-e-o-terceiro-maior-de-sempre-no-mundo-302-infetados-e-sete-mortos=f897829 (accessed on 11.06.2015).

Barrymore, K. (1994). Legionella Liability 'A Legal Minefield' - Legionnaires Disease: New Outbreak Expected To Hit Our Cities. Australian Financial Review, April 8, 1994. (accessed on January 18, 2014).

FEMA (2015). Security Risk Management Series Publications. Federal Emergency Management Agency. Available at:http://www.fema.gov/what-mitigation/security-risk-management-series-publications (accessed on 12.06.2015).

Globe \& Mail (1978). Spread by airborne droplets? Legionnaire's disease linked to water. Globe and Mail from New York Times Service, September 4, 1978, p. 10. Available at: https://news.google.com/newspapers?nid=145 4\&dat=19780903\&id=bLssAAAAIBAJ\&sjid=LRMEAAAAIBAJ\&pg=2736,405917\&hl=en (accessed on 12.06.2015).

Hanus, J., Hanusová, E. (2011): Archive building - the basic condition for proper function of archives. In: Tehnični in usebinski problemi klasičnega in elektronskega arbiviranja - Technical and field related problems of traditional and electronic archiving": 10. zbornik referatov [Radenci, Slovenija, April 6-8, 2011], pp. 217-226. Maribor. Pokrajinski arhiv. 
Hanus, J., Hanusová, E. (2012): Appropriate Archival Building: Necessity for Proper Function of Any Archives. In: ATLANTI, Vol. 22, N. 1., pp. 61-69. Trieste: International Institute for Archival Science of Trieste and Maribor, University of Maribor, State Archive of Trieste.

Hanus, J., Vizárová, K., Jablonský, M. (2014): Degradácia a ochrana objektov kultúrneho dedičstva na báze lignocelulózových materiálov z hladiska mikrobiálnej kontaminácie. In: Zbornik vedeckých konferencií WPP PA Wood, Pulper Paper Polygrafia Academica 2014, Bratislava 12.-13. marca 2014, pp. 259-264.

Klasinc, P. P. (2009). The Activities of the International Institute for Archival Science of Trieste and Maribor in 2008 and 2009. In: Atlanti, Vol. 19, pp. 25-31. Trieste: International Institute for Archival Science of Trieste and Maribor, University of Maribor, State Archive of Trieste.

Klasinc, P. P. (2010). The Activities of the International Institute for Archival Science of Trieste and Maribor in 2009-2010 and Presentation of the 20 Issues of "Atlanti" (1991-2010). In: Atlanti, Vol. 20, pp. 27-40. Triste: International Institute for Archival Science of Trieste and Maribor, University of Maribor, State Archive of Trieste Trieste.

Kotulak, R. (1986). Legionnaires' Disease Less Mysterious, Still Deadly. Chicago Tribune, August 31, 1986. Available at: http://articles.chicagotribune.com/1986-08-31/news/8603050199_1_legionnaires-disease-watertower-rare-disease (accessed on 11.06.2015).

Sanosil Ltd. (2013). Available at: http://sanosil.com/ (accessed on 12.06.2015).

Sanosil-Slovakia (2012). Available at: http://www.sanosil-slovakia.sk/ (accessed on 12.06.2015).

Time (1976). The Philadelphia Killer, Time August 16, pp. 64-65.

UK Government Advice (2007). UK Government Advice on Definition of an Emergency (accessed on 30.05.2007).

UK Guidance (2006). UK Guidance Emergency preparedness. Gov. UK Cabinet Office, January 2006. Available at: https://www.gov.uk/government/uploads/system/uploads/attachment_data/file/61024/Chapter-1-Introduction_amends_16042012.pdf) (accessed on 12.06.2015).

WBDG (2014a). Secure / Safe. WBDG Secure/Safe Committee. Last updated: 08-18-2014. Available at: http:// www.wbdg.org/design/secure_safe.php (accessed on 12.06.2015).

WBDG (2014b). Security for Building Occupants and Assets. WBDG Secure/Safe Committee. Last updated: 10-21-2014. Available at: http://www.wbdg.org/design/provide_security.php (accessed on 12.06.2015).

\section{SUMMARY}

Preservation of archival documents, library materials and other objects and materials of cultural heritage is one of the principal tasks of archives, libraries, museums, galleries and other cultural memory institutions all over the world. The key role in this mission is played by appropriate building or space facilities which are the basic condition and requirement for proper functioning of any of these memory cultural institutions. They must provide not only facilities for long-term storage of archival documents, library materials and other objects of cultural heritage, their preservation, processing, treatment in order to enable and ensure proper and safe access to them but also to respond possible emergencies resulting from various potential emergencies and even threats. Some of them can be predicted, however, the others - especially caused by human factor - are very difficult to be foreseen. On the basis of all these information and development of the human society at present times it is obvious that the protection against buildings threats emergencies has been shifted from the sphere of possible technical failings and natural disasters to the protection against emergencies caused by intentional human behaviour. On the other hand, the information about possible negative and even mortal impact of microbiological contamination on human beings caused by such obvious and frequently used systems such as air-conditioning is the challenge that the thorough checking of all risk factors and the elimination of these potential threats from archives, libraries, museums and galleries is of the same importance.

Typology: 1.02 Review Article

Submitting date: 15.03 .2015

Acceptance date: 09.04.2015 
